\title{
Relationship of Commitments to Teacher Performance
}

\author{
Nellitawati ${ }^{1 *}$ \\ ${ }^{I}$ Department of Education Administration, Faculty of Education, Universitas Negeri Padang,Padang, Indonesia \\ *Email: nellitawati@fip.unp.ac.id
}

\begin{abstract}
The teacher must have good performance so that educational goals can also be realized. However, several phenomena show that there are teachers who have low performance, one of the contributing factors is the lack of teacher commitment to the task. This study aims to analyze the teacher's commitment to the task, teacher performance, and the relationship between the two. Using the Causal Comparative (Ex Post Facto) method, with a sample of 72 people. The instrument used was the Commitment and Teacher Performance Inventory. Data analysis techniques using the normality test and homogeneity test. The results showed that there was a significant relationship between commitment and teacher performance Keywords: commitment, teacher performance, educational goals
\end{abstract}

\section{INTRODUCTION}

One important factor in determining the success of a school is teacher performance [1]-[3]. Performance is a comparison of actual achievements that can be achieved with expected work performance. Performance with work performance is the success of an individual in carrying out the tasks and responsibilities at work [4]. Teacher performance is the result achieved from a job carried out by the teacher as a teacher and as a manager of the teaching and learning process in achieving the expected goals [5]-[7]. Ideally, every teacher has good teacher performance, because it will help the smooth implementation of the task in achieving educational goals. But it's a little different from the results found at school. There are several phenomena found 1) The teacher does not make a teaching plan, lacks mastering the material in teaching, does not use the method, so students find it difficult to understand the lesson. Another very substantial symptom is part; 2) The teacher is not serious in carrying out his task, this can be seen from the way the teacher to compact his teaching hours so he does not have the time and opportunity to help and guide students who have learning difficulties, lack of responsibility in teaching students so that the child's learning completeness is not fulfilled as required is expected. This suggests that the teacher's commitment to the task is far from what was expected.

Commitment is a decision or agreement of someone with himself to do or not do, stop or continue an action or activity [8]-[10]. Commitment can also be interpreted as a tendency in someone to feel actively involved with a full sense of responsibility. Commitment is not just involvement, commitment is the willingness of someone to be actively involved in an activity with high responsibility.

\section{METHOD}

The method used in this study is the Causal Comparative (Ex Post Facto) method which will reveal the relationship between teacher commitment to the task and teacher performance in SLTP Negeri Koto Tangah District Padang. The research sample was 72 people, which were obtained through the technique of taking stratified proportional random sampling. The instrument used was the Commitment and Teacher Performance Inventory. The research instrument was prepared based on the indicators of each variable, namely regarding the commitment of teachers to the tasks and performance of teachers. The instrument consisted of 67 items with 32 items of teacher commitment to the task and 35 items of teacher performance. Subsequent research data were analyzed using a normality test and sample homogeneity test.

\section{RESULTS AND DISCUSSION}

The results of data processing about the teacher's commitment to the task and teacher performance can be seen in Table 1 below. 
Table 1 Distribution of commitment and discipline data for teacher work

\begin{tabular}{|c|c|c|c|c|c|c|c|}
\hline \multirow[b]{2}{*}{ Variable } & \multirow[b]{2}{*}{ Mean } & \multirow[b]{2}{*}{$\begin{array}{c}\text { Ma } \\
\text { X }\end{array}$} & \multicolumn{3}{|c|}{ Category (\%) } & \multirow{2}{*}{$\begin{array}{c}\% \text { Ideal } \\
\text { Scor }\end{array}$} & \multirow[b]{2}{*}{ Cat. } \\
\hline & & & $\begin{array}{l}\text { Very } \\
\text { Good }\end{array}$ & Good & $\begin{array}{c}\text { Les } \\
\mathrm{s}\end{array}$ & & \\
\hline $\begin{array}{c}\text { Teacher's } \\
\text { commitment to } \\
\text { the task }\end{array}$ & 111,43 & 140 & 19,50 & 50,00 & $\begin{array}{c}30,5 \\
0\end{array}$ & 80,00 & Good \\
\hline $\begin{array}{c}\text { Teacher } \\
\text { performance }\end{array}$ & 119,83 & 140 & 40,30 & 38,90 & $\begin{array}{c}20,8 \\
0\end{array}$ & 85,59 & Good \\
\hline
\end{tabular}

Table 1 shows that the teacher's commitment to the task is in a good category $(80.00 \%)$ of the ideal score, while the teacher's performance is also in the good category $(85.59 \%)$ of the ideal score. $19.50 \%$ of respondents stated that the teacher's commitment to the task was in the very good category, $50 \%$ of the respondents stated that the teacher's commitment good, and only $30.5 \%$ of respondents said that the teacher's commitment to the task was in the unfavorable category. Likewise, with teacher performance, $40.30 \%$ of respondents stated that teacher performance was in the very good category, $38.90 \%$ of respondents stated that teacher performance was in a good category, and $20.80 \%$ of respondents stated that teacher performance was still lacking.

Based on the summary description of the data in table 1 above it can be concluded that the commitment to the task and teacher performance good (80\%), and this needs to be maintained and even improved.

The results of the normality requirements test show that the Chi-Square coefficient $\left(\chi^{2}\right)$ variable of the teacher's commitment to the task with $\mathrm{dk}=9$ is 5.539 and $\mathrm{p}>0.05$. Likewise, the Chi-Square coefficient $\left(\chi^{2}\right)$ teacher performance variable with $\mathrm{dk}=9$ is 7.706 and $\mathrm{p}>0.05$. This means that the data to the two variables are distributed. Likewise, the data homogeneity requirements test got by the Chi-Square Barlett value of 0.908 with $p=$ 0.962 , means that the group variance is homogeneous.

The results of the statistical test of the research hypothesis "There is a significant relationship between the commitment of teachers to the task with the performance of teachers in SLTP Negeri Koto Tangah Padang District" shows that the correlation coefficient $(\mathrm{rxy})=0.644$ and $\mathrm{p}$ $<0.01$. Based on the results of the statistical tests conducted above it can be concluded that the research hypothesis proposed, namely "There is a meaningful relationship between teacher commitment to the task with teacher performance in the SLTP Negeri Koto Tangah Padang District" can be accepted.

School principals need to strive to improve teacher performance through enhancing a teacher's ability and instilling a sense of responsibility in teachers in carrying out tasks so that educational goals can be achieved to the maximum [11]-[14].
In line with the level of teacher performance achievement of $85.59 \%$. This score is in the high category. This condition needs to be maintained and improved, by (1) the application of a good teacher discipline needs to be improved, so that every teacher feels treated fairly, (2) giving a good example from the principal is still needed, (3) the need to foster a sense of ownership in every teacher, (4) school activities that can generate additional income for teachers need to be created and distributed fairly and evenly.

The good mapping pattern of SLTPN teachers in the Koto Tangah Padang District needs to be maintained and improved. Teacher mapping patterns should be based on the area of expertise and qualifications of each teacher and tailored to the needs of the school. Furthermore, the development of the field of expertise needs to be considered, so there is no overlapping in the field between teachers. Besides that, it is necessary to carry out continuous and programmed guidance to improve the performance of teachers in SLTPN, Koto Tangah District, Padang

\section{CONCLUSION}

Based on the results of the research that has been done can be concluded several things: 1) Commitment of teachers to the task and performance of teachers in SLTP N District Koto Tangah Padang are in good categories, the level of achievement of each research variable is $80 \%$ and $85.59 \%$ of an ideal score. This level of achievement can still be improved through teacher mapping patterns appropriate to their respective fields of expertise, and patterns of development and improvement of teacher quality under the needs of the school and refer to the needs of the user community (stakeholders); 2) The teacher's commitment to the tasks and performance of teachers in SLTP N, Koto Tangah District, Padang has a significant relationship at a significance level of $5 \%$ with a correlation coefficient of 0.644 rxy. This suggests that efforts to improve teacher performance can be done through efforts to increase teacher commitment to the task. 


\section{REFERENCES}

[1] L. Darling-Hammond, "Evaluating Teacher Effectiveness: How Teacher Performance Assessments Can Measure and Improve Teaching.," Cent. Am. Prog., no. October, pp. 1-36, 2010.

[2] T. S. Dee and J. Wyckoff, "Incentives, Selection, and Teacher Performance: Evidence from IMPACT," $J$. Policy Anal. Manag., vol. 34, no. 2, pp. 267-297, 2015.

[3] E. S. Taylor and J. H. Tyler, "The Effect of Evaluation on Teacher Performance," Am. Econ. Rev., vol. 102, no. 7, pp. 3628-3651, 2012.

[4] D. Lerner et al., "Work Performance of Employees With Depression: The Impact of Work Stressors," Am. J. Heal. Promot., vol. 24, no. 3, pp. 205 $213,2010$.

[5] D. Goldhaber and M. Hansen, "Using performance on the job to inform teacher tenure decisions," Am. Econ. Rev., vol. 100, no. 2, pp. 250-255, 2010.

[6] C. M. Guarino, M. D. Reckase, and J. M. Wooldridge, "Can value-added measures of teacher performance be trusted?," Educ. Financ. Policy, vol. 10, no. 1, pp. 117-156, 2015.

[7] D. N. Harris and T. R. Sass, "Skills, Productivity and the Evaluation of Teacher Performance," Econ. Educ. Rev., vol. 40, pp. 183-204, 2014.
[8] T. C. Blanchard, C. E. Strait, and B. Y. Hayden, "Ramping Ensemble Activity in Dorsal Anterior Cingulate Neurons During Persistent Commitment to a Decision," $J$. Neurophysiol., vol. 114, no. 4, pp. 2439-2449, Oct. 2015.

[9] G. Bryan, D. Karlan, and S. Nelson, "Commitment Devices," Annu. Rev. Econom., vol. 2, no. 1, pp. 671-698, 2010.

[10] M.-H. Tsai and M. J. Young, “Anger, Fear, and Escalation of Commitment," Cogn. Emot., vol. 24, no. 6, pp. 962-973, Sep. 2010.

[11] N. Nellitawati, "Motivation and Innovation Role of School's Principal in Improving Teacher Professionalism," COUNS-EDU Int. J. Couns. Educ., vol. 3, no. 2, pp. 48-56, 2018.

[12] N. Nellitawati, "The Contribution of Headmaster's Personality Competence to the Teacher's Social Competence of Vocational High School," COUNSEDU Int. J. Couns. Educ., vol. 2, no. 1, p. 25, 2017.

[13] N. Nellitawati, "The Role of the Headmaster and Pedagogical Competences of Teacher in Vocational School," J. Konseling dan Pendidik., vol. 5, no. 2, p. 102, 2017.

[14] N. Nellitawati and Y. Boon, "The Role of Headmaster to Improve Pedagogic Competence of Teachers in Vocational High School," Tech. Technol. Educ. Manag., vol. 12, no. 3, pp. 207-213, 2017. 